\title{
柔軟な拡大翼モデルによる蚊の羽ばたき挙動の再現
}

\author{
加瀬 篤志*1, 加藤 勇希 ${ }^{* 2}$, 吉田 直之*3, 田地川 勉 ${ }^{* 4}$, 板東 潔*4
}

\section{The imitating flapping behaviour of mosquito using flexible wing model}

\author{
Atsushi KASE ${ }^{* 1}$, Yuki KATOH ${ }^{* 2}$, Naoyuki YOSHIDA ${ }^{* 3}$, Tsutomu TAJIKAWA ${ }^{* 4}$ and Kiyoshi \\ $\mathrm{BANDO}^{* 4}$ \\ ${ }^{* 1}$ Department of Mechanical and Intellectual Systems Engineering, University of Toyama \\ 3190 Gofuku, Toyama-shi, Toyama 930-8555, Japan \\ ${ }^{* 2,3}$ Faculty of Engineering Science, Kansai University \\ 3-3-35 Yamate-cho, Suita-shi, Osaka 564-8680, Japan \\ ${ }^{* 4}$ Department of Mechanical Engineering, Kansai University \\ 3-3-35 Yamate-cho, Suita-shi, Osaka 564-8680, Japan
}

\section{Received 24 June 2015}

\begin{abstract}
The mosquito's wing is deforming during flapping stroke and the pitching angle is changed. The motion called "feathering motion" is considered that the wing is deformed passively by the aerodynamic force. But it is not established yet. In this paper, first, the bending stiffness of mosquito's wing for chord direction was measured with cantilever. Secondly, the flexible 10 times enlarged wing models which have same planar shape and wing area and different thickness were made with Polyphenylenesulfide resin films. Finally, the behavior of each enlarged wing models during flapping motion in the wind tunnel was measured and was compared with the motion of the real mosquito's wing. Then, both Reynold number and Strouhal number of model experiments were conformed to those of real mosquito. The results of measuring the bending stiffness of mosquito's wing for the chord direction showed the wide range values from 2 to $125 \mathrm{pNm}^{2}$ and the averaged value of $53 \mathrm{pNm}^{2}$. The results for the enlarged wing model showed that the amplitude of change of inclination angle during flapping motion decreased as the thickness of film increased. The enlarged wing model in which the bending stiffness was almost similar to that of real mosquito's wing showed the feathering motion like those of the real mosquito.
\end{abstract}

Key words : Mosquito, Insect flight, Flapping wing, Enlarged model, Fethering motion, Flexible wing

\section{1. 緒 言}

近年，小型飛翔体（MAV;Micro Air Vehicle, NAV;Nano Air Vehicle）の開発が盛んであり，人が立ち入れな い領域での活動や，過疎地域への物資運搬等の用途で無人機いわゆるドローンとして実用化され始めている. し かし，その多くは回転翼による飛行であり，小型化や高効率化には限界があり，より小型で効率の良い小型飛翔 体の開発には回転翼とは別の飛行方式を採用する必要があると考えられる。そこで回転翼に代わる飛行方式とし て注目されているのは，鳥や蝙蝠，昆虫等の生物が行っている羽ばたき飛行である. 特に，昆虫は全長が数 mm 数 $\mathrm{cm}$ のオーダーでありながら巧みな飛行を披露しており, 昆虫の飛行方式を解明すれば小型飛翔体の高性能化 への糸口がつかめる可能性が高い.

トンボやスズメガ等の大型昆虫に関しては比較的多くの研究がなされている（例えば, 須藤他, 1994, Sudhakar and Vengadesan, 2009 等). それに対し, 八チや八エ・蚊等の比較的小型の昆虫については研究報告例が少ないと いうのが現状である。これらの小型昆虫は生物の進化の系統としては後発の種であり，トンボ等の比較的古い種

No.15-00347 [DOI:10.1299/transjsme.15-00347], J-STAGE Advance Publication date : 4 December, 2015

*1 正員, 富山大学 工学部（T930-8555 富山県富山市五福 3190)

*2 学生員, 関西大学大学院 理工学研究科（干564-8680 大阪府吹田市山手町 3-3-35)

*3 関西大学大学院 理工学研究科

${ }^{* 4}$ 正員, 関西大学 システム理工学部

E-mail of corresponding author: kase@eng.u-toyama.ac.jp 
よりも進化した飛行方式を実現していることが知られている，そこで，我々は小型昆虫の中でも比較的身近に存 在する蚊に着目し，蚊の羽ばたき運動の観測や揚力の実測，拡大模擬実験などにより，その飛行メカニズムの解 明に取り組んできた（有田他，2011，加瀬他，2012）。

昆虫の飛行方式は一般に前翅一対と後翅一対の計 4 枚の翅を羽ばたかせることで揚力及び推力を得ている．し かし，蚊の属する八エ目（双翅目）の昆虫は後翅が平均棍と呼ばれる一種のジャイロに進化し，前翅一対のみの 羽ばたき運動により飛行を実現しており，昆虫の飛行の中でも特に進化した飛行方式を取っている．その羽ばた き運動には，翅を上下に往復させるフラッピング運動，翅を前後に往復させるリード・ラグ運動，そして翅の迎 え角を変更するフェザリング運動と呼ばれる大きく分けて 3 つの動きが含まれており, ワンストローク中にこれ ら 3 つの動きをコントロール寸ることで効率的な飛行を実現している．ただし，その羽ばたき周波数は約 $500 \mathrm{~Hz}$ であり, 神経制御できる速度を遥かに超えており, 特にフェザリング運動を如何にして制御しているかは, 大き な謎である.これに対し我々は，翅がフラッピング運動及びリード・ラグ運動時に受ける流体力により翅が受動 的に変形することによりフェザリング運動を実現している可能性に着目した.

本報告では，柔軟な材料で作製した拡大翼モデルを用いて，受動的変形により迎え角変更を実現し，実際の蚊 の羽ばたき動作中にみられるフェザリング運動の模擬が可能かどうかを検討した結果について述べる.

\section{2. 蚊の翅の曲げ剛性測定}

フェザリング運動が翅の受動的変形によるものであるとすれば，この運動に対して主に関連する要素は翅の翼 弦方向の曲げ剛性であると考えられる．そこでまず蚊の翅の翼弦方向の曲げ岡性の測定を行った.

図 1 に蚊の翅の翼弦方向の曲げ剛性の測定に用いた装置の概略図を示す，上下に動くステージを向い合せに設 置し，一方には蚊の翅を固定，もう一方には真鍮線で作製したカンチレバー（ヤング率 $E_{B}=100.3 \mathrm{GPa}$, 断面二次 モーメント $I_{B}=3.98 \times 10^{-16} \mathrm{~m}^{4}$ ， うでの長さ $\left.L_{B}=80 \mathrm{~mm}\right)$ を取り付けてある. 蚊の翅は図 2 のように前縁部を板に 挟み込んでステージの端に水平に固定し, 後縁部にカンチレバーの先端があたるように設置する. その状態でカ ンチレバー側のステージを上昇させて翅付け根側からカメラで撮影し, 翅の後縁部のたわみ量 $z_{W}$ とカンチレバー 先端のたわみ量 $z_{B}$ を測定する.

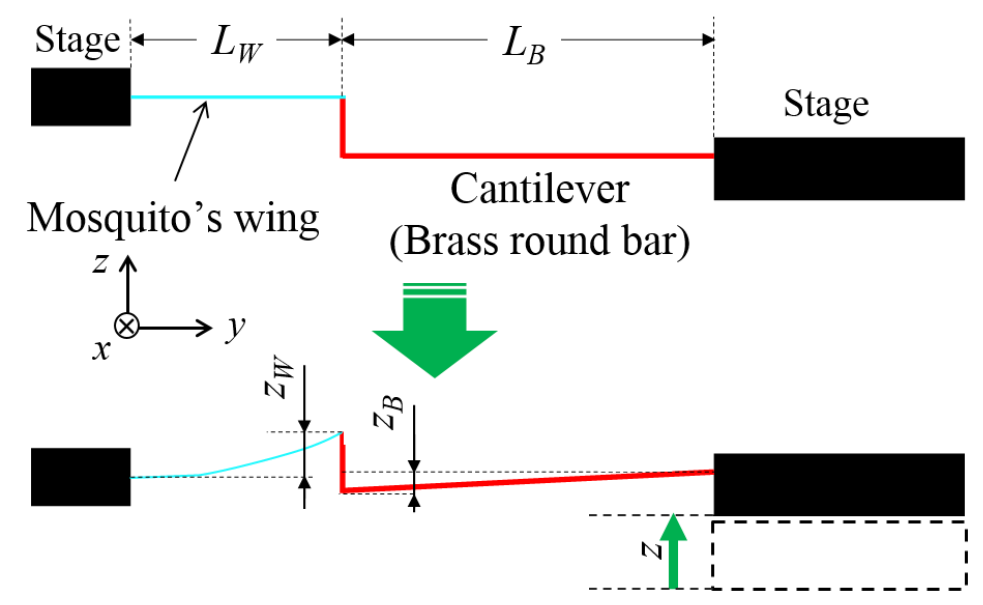

Fig. 1 The schematic of experimental setup for measuring bending stiffness of mosquito's wing. The leading edge of mosquito's wing is fixed on the end of left side stage. The cantilever beam is fixed on the right side stage and its tip is placed on the trailing edge of mosquito's wing.

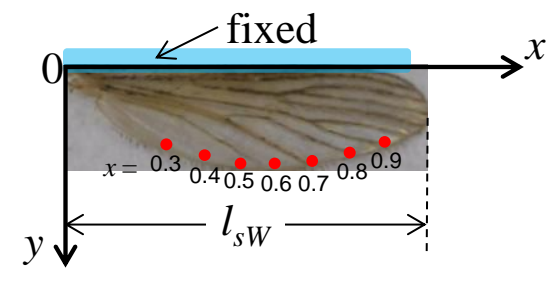

Fig. 2 The fixation of mosquito's wing. The leading edge is fixed to measure the bending stiffness for the chord direction. The red points on the trailing edge show the measuring points on which the tip of cantilever beam is placed. 
ここで，翅及びカンチレバーを片持ち梁と見做し，自由端での集中荷重を仮定すると，たわみの基礎式より，

$$
\begin{gathered}
z_{W}=\frac{F_{W} L_{W}^{3}}{3 E_{W} I_{W}} \\
z_{B}=\frac{F_{B} L_{B}^{3}}{3 E_{B} I_{B}}
\end{gathered}
$$

が得られる．ここに， $L_{W}$ は翅の翼弦長， $E_{W} I_{W}$ は翅の曲げ岡性を示す．また $F_{W}, F_{B}$ は翅及びカンチレバーに作用 する力をそれぞれ示している．作用反作用の法則から $F_{W}=F_{B}$ であるので，式(1)，(2)より次式が得られる.

$$
E_{W} I_{W}=\frac{z_{B} L_{W}^{3}}{z_{W} L_{B}^{3}} E_{B} I_{B}
$$

式(3)において $L_{w}, L_{B}$ 及び $E_{B} I_{B}$ は既知であり，たわみ量 $z_{B}$ 及び $z_{W}$ を測定することで $E_{W} I_{W}$ が求められる.

図 2 に赤い点で示寸測定箇所にカンチレバー先端が当たるようにステージを配置して翅及びカンチレバーのた わみ量を測定し, 翅ごとに平均值を求めて翅全体の平均的な曲げ岡性とした．10枚の翅に対して曲げ剛性を測定 した結果, 最大で $125 \mathrm{pNm}^{2}$, 最小で $2 \mathrm{pNm}^{2}$, 平均約 $53 \mathrm{pNm}^{2}$ となった. 曲げ剛性の測定結果が大きな幅を持っ た原因としては, 計測精度の問題に加えて, 翅の個体差や乾燥状態等の違いが挙げられる. さらに, 図 2 を見て も分かるように, 翅はその構造を支える比較的固い翅脈部と薄くてほぼ透明な膜状の部分で構成されており, カ ンチレバーの接触位置がどちらにあるかによっても, 測定結果が大きく異なることが考えられる. 翅の曲げ剛性 のより精度の高い測定については, 今後の検討課題である. ただし, 実際には翅全体で力を受け持つため, フェ ザリング運動を考慮する上では局所的な曲げ岡性ではなく, 翅全体としての平均的な曲げ剛性が重要と考えられ る. ここで, 曲げ岡性が最大の值を示した結果はカンチレバー先端が主に翅脈部に接していた場合であり, 最小 の結果は主に膜の部分で測定していたと考えると, 平均值では翅脈と膜の部分を平均的に捉えていると言える. 従って, 翅の翼弦方向の曲げ岡性としては, 測定結果の平均值である約 $53 \mathrm{pNm}^{2}$ を用いることが妥当であると考 えられる。

\section{3. 柔軟な拡大翼モデルの作製}

翅の断面を矩形と見做すと，断面二次モーメント $I_{W}$ は厚さの三乗に比例して増加する．そこで，同一材料で厚 さ $h_{m}$ の異なる拡大モデルを作製し, 剛性の違いによる羽ばたき挙動の変化を調べた. 今回は PPS 樹脂（ヤング 率 $\left.E_{M}=4.0 \mathrm{GPa}\right)$ で出来たフィルム（トレリナ®，東レ製）を用いて，実際の蚊の翅を 10 倍に拡大した平面形状 を持つ翼モデルを作製する. フィルムの厚さは $2,4,6 \mu \mathrm{m}$ のものを用い, 識別のためそれぞれモデル $\mathrm{A}, \mathrm{B}, \mathrm{C}$ と呼称することにする. 各モデルの翼弦方向の曲げ岡性 $E_{M} I_{M}$ を計算すると, モデル $\mathrm{A}$ は約 $62 \mathrm{pNm}^{2}$, モデル B は約 $0.49 \mathrm{nNm}^{2}$, モデル C は $1.66 \mathrm{nNm}^{2}$ であった. ここで蚊の翅の曲げ岡性 $E_{W} I_{W}$ として平均值である $53 \mathrm{pNm}^{2}$ を 採用すると, $h_{M}=2 \mu \mathrm{m}$ のモデル A が最も蚊の翅に近い曲げ岡性を有する. なお各モデルの断面二次モーメント $I_{M}$ の計算においては, 断面を矩形とし, 翼幅を翼弦方向位置の関数として与えた.

図 3 に柔軟な拡大翼モデルの構成の概略図を示す. PPS フィルムを蚊の翅の形状に切り出し, 前縁部に接着し た直径 $0.3 \mathrm{~mm}$ のピアノ線を介して羽ばたき装置に取り付けるようになっている. ここで, 前縁部のピアノ線は, 翼幅方向への変形を抑制し，翼弦方向のみ変形できるようにするために用いている．実際の蚊の翅においても前 縁部に比較的太い翅脈があり，本モデルはこれに倣った構造をとっている．またピアノ線は，前縁部のほぼ直線 と見做せる翼幅の約 75\%まで接着し，PPS フィルムと羽ばたき装置の基部との間には，接触してフェザリング運 動を妨げることが無いように $2 \mathrm{~mm}$ の隙間を設けている. 今回は, 翼幅 $l_{s M}$ を $34 \mathrm{~mm}$, 翼弦長 $l_{c M}$ を最大 $9.7 \mathrm{~mm}$, 平均約 $6 \mathrm{~mm}$ とし, 翼面積が約 $238 \mathrm{~mm}^{2}$ の翼モデルを作製した。また, 羽ばたき運動時のフェザリング挙動を確 認するため，翼幅の $25 \% ， 50 \% ， 75 \%$ の位置に前縁と垂直な線を書き入れ，目印とした。 


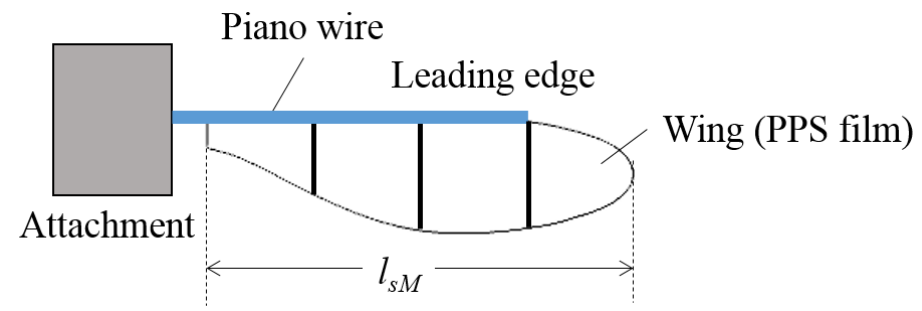

Fig. 3 The schematic of the enlarged flexible wing model. The leading edge of the wing made with PPS film is adhered the piano wire which is connected to the flapping machine. The wing has put marks at $25 \%, 50 \%$ and $75 \%$ of span length.

\section{4. 柔軟翼モデルの羽ばたき挙動測定}

\section{$4 \cdot 1$ 実験装置と方法}

図 4(a)に柔軟翼モデルの羽ばたき挙動の計測に用いた実験装置全体の概略図を示す. 微風速風洞（旭流熱シス テム製）内に設置した羽ばたき装置に上記翼モデルを取り付け，一様気流中で羽ばたき運動させる。 その様子を 風洞側面に設置したハイスピードカメラ（FASTCAM-MAX120KC，Photron 製）で記録する. 羽ばたき装置（有 田他，2011，加瀬他，2012）は，風洞外部に設置されたモーターからの動力で駆動するロッドの往復運動を図 4(b) に示すように往復回転運動 (フラッピング運動) に変換する機構となっている.また羽ばたき平面を鉛直から $30^{\circ}$ 傾けることでリード・ラグ運動も考慮できるようになっている.

各翼モデルのフェザリング運動を評価するため，撮影した画像から翼面上の目印をつけた位置で図 5 のように 主流方向と前縁と後縁を結ぶ直線となす角度で定義した傾き角 $\alpha$ を測定した。 その際，光源にはLED ランプを使 用し, 風洞下部から照射し, フレームレート $500 \mathrm{fps}$ で撮影した. また実際の蚊の飛行速度 $V_{W}$ を $1.0 \mathrm{~m} / \mathrm{s}$ (東, 1997), 羽ばたき周波数 $f_{W}$ を $500 \mathrm{~Hz}$ (甲斐，大場，2001，有田他，2011）であると想定し，空気の動粘度をvとして式(4), (5)で定義されるレイノルズ数 Re 及びストローハル数 $S t$ が一致するように，風洞内の流速 $V_{M}$ を $0.1 \mathrm{~m} / \mathrm{s}$, 羽ばた き装置の羽ばたき周波数 $f_{M}$ を $5 \mathrm{~Hz}$ に設定した. なお式(4), (5)の定義では, Re $\fallingdotseq 40, S t \fallingdotseq 0.8$ あるる。また風 洞主流速度の $0.1 \mathrm{~m} / \mathrm{s}$ は, 使用した微風速風洞の低速限界であり, テストセクション内の乱れ度は約 $8 \%$ あるる.

$$
\begin{gathered}
R e=\frac{V_{W} l_{c W}}{v}=\frac{V_{M} l_{c M}}{v} \\
S t=\frac{f_{W} l_{c W}}{V_{W}}=\frac{f_{M} l_{c M}}{V_{M}}
\end{gathered}
$$

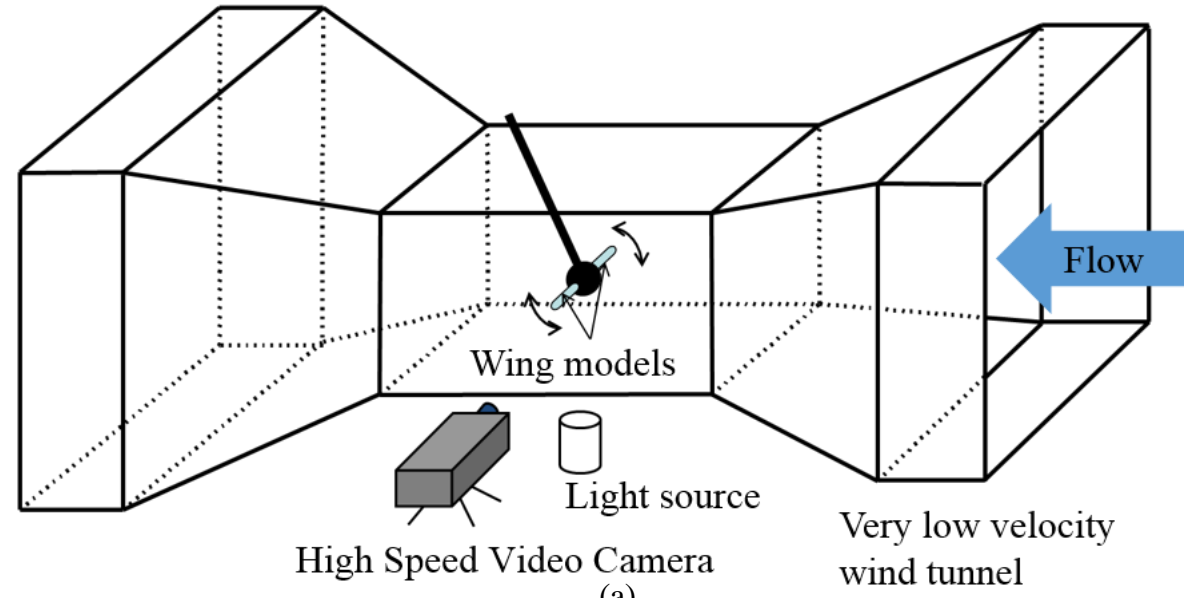

(a)

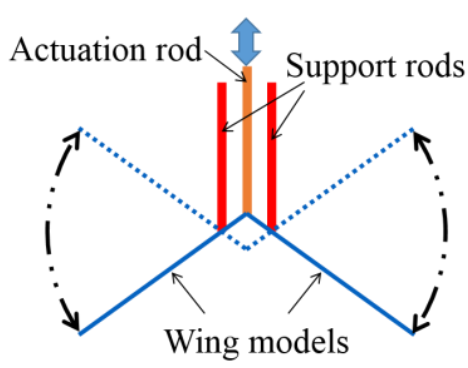

(b)

Fig. 4 The schematic of the experimental setup. (a) Whole of the experimental setup. (b) Flapping machine. The flapping machine installed as the wing model is set in the very low velocity wind channel and is operated with the condition that is both Reynold number and Strouhal number are similar to those of real mosquitos. 


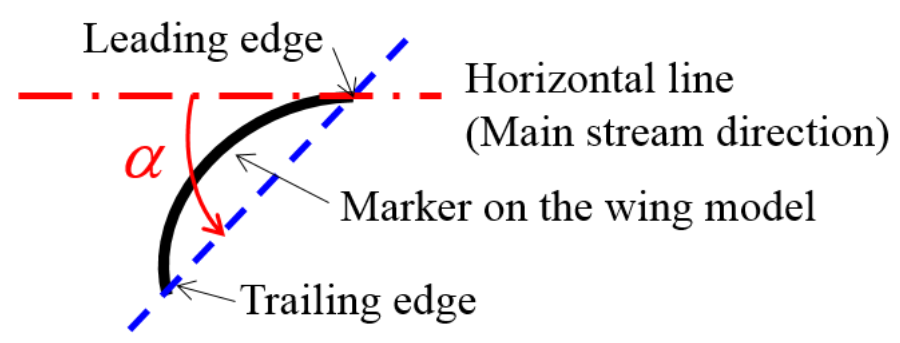

Fig. 5 The definition of the inclination angle. The inclination angle $\alpha$ is defined as the angle between the horizontal line and the line connecting leading edge and trailing edge at the mark on the wing.

\section{$4 \cdot 2$ 傾き角の測定結果}

図 6 に各モデルにおける傾き角 $\alpha$ の測定結果を示す。ただし横軸は羽ばたき周期 $T$ で無次元化した時間を示し ており， $0 \leqq t / T \leqq 0.5$ が打ち下ろし， $0.5 \leqq t / T \leqq 1$ が打ち上げの位相である．また各図には，実際の蚊の羽ばたき動 作の撮影（甲斐，大場，2001）から得られた翼幅の約 70 80\%の位置での傾き角の変動を黒丸プロットで示して いる.さらに，各プロットの最小二乗近似曲線を実線で示している.

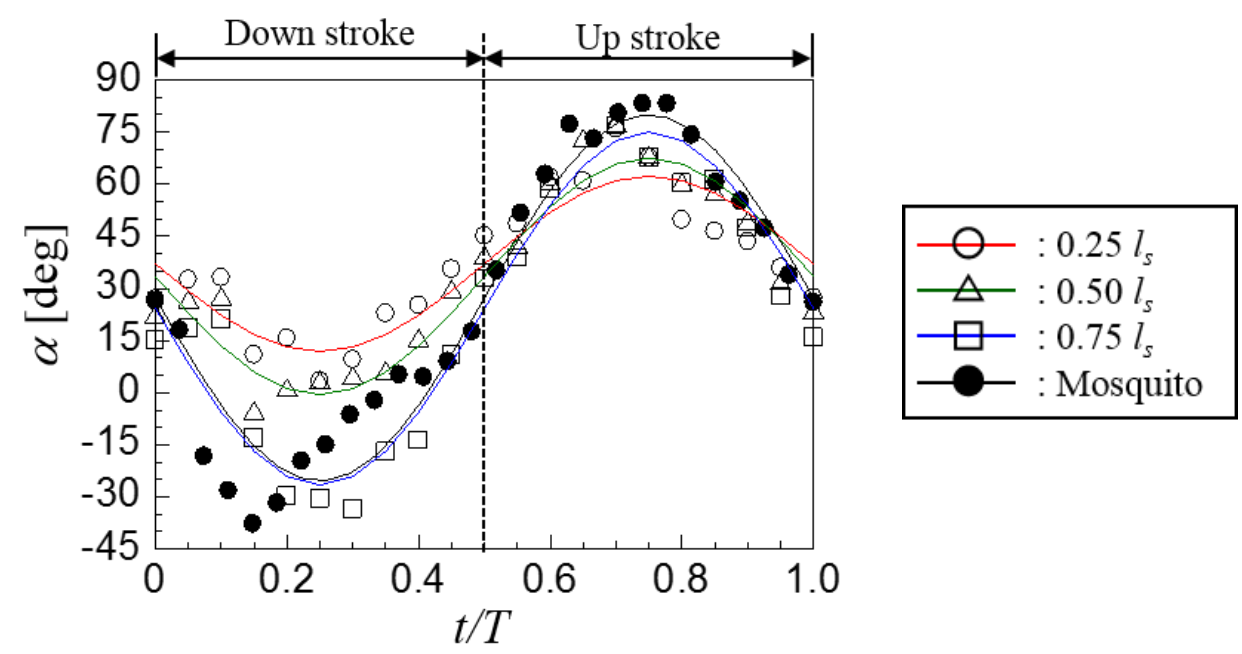

(a) Model A $\left(h_{M}=2 \mu \mathrm{m}, E_{M} I_{M}=62 \mathrm{pNm}^{2}\right)$

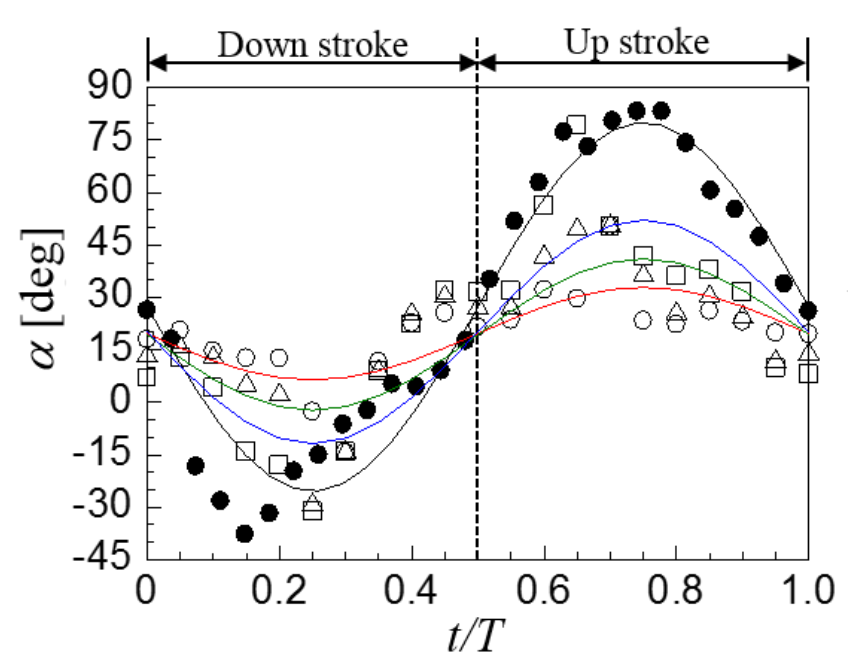

(b) Model B $\left(h_{M}=4 \mu \mathrm{m}, E_{M} I_{M}=0.49 \mathrm{nNm}^{2}\right)$

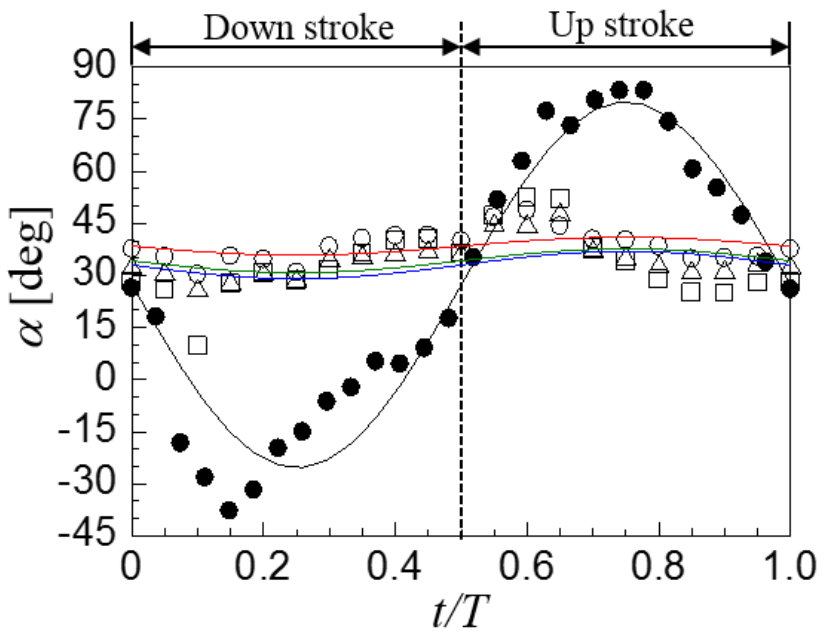

(c) Model C $\left(h_{M}=6 \mu \mathrm{m}, E_{M} I_{M}=1.66 \mathrm{nNm}^{2}\right)$

Fig. 6 The periodic changes of the inclination angle $\alpha$ of 3 wing models. The thickness of model A, B and C is 2, 4 and $6 \mu \mathrm{m}$ respectively. The periodic change of model A is similar to that of real mosquito. The bending stiffness of model A is approximately corresponded with that of real mosquito. 
図 6 から，モデルの膜厚 $h_{M}$ が増加，すなわち曲げ岡性 $E_{M} I_{M}$ が増加すると，傾き角 $\alpha$ 振幅が小さくなること が分かる. また，各モデルにおいて翼端（1.0l $\left.l_{s}\right)$ に近いほど $\alpha$ 振幅が大きい. これは，翼端に向かうにつれて周 速度が増加することによるものと考えられる. 一方, 実際の蚊の翅で測定された曲げ剛性 $E_{M} I_{M}$ と近い值を示すモ デル A において，実際の蚊と同様の $\alpha$ の時間変化を示した。すなわち，実際の蚊と同様のフェザリング運動を再 現した. これは，実際の蚊においても羽ばたき動作中に受ける流体力により受動的に翅が変形してフェザリング 運動を実現していることを示唆している，また，その再現には，10 倍拡大モデルにおいても実際の翅と同程度の 曲げ剛性を与える必要があることを示している.

\section{5. 相似則に基づく考察}

蚊の翅及び翼モデルの翼弦方向を片持ち梁とし，等分布荷重 $P$ が作用すると仮定すると，それぞれの最大たわ み角 $\alpha$ は，たわみの基礎式より次式で表される。

$$
\begin{aligned}
& \alpha_{W}=\frac{P_{W} l_{c W}^{3}}{6 E_{W} I_{W}} \\
& \alpha_{M}=\frac{P_{M} l_{c M}^{3}}{6 E_{M} I_{M}}
\end{aligned}
$$

また，等分布荷重 $P$ として羽ばたき運動時の動圧を考えると，

$$
\begin{aligned}
& P_{W}=\frac{1}{2} \rho V_{W}^{2} l_{s W} \\
& P_{M}=\frac{1}{2} \rho V_{M}^{2} l_{s M}
\end{aligned}
$$

が得られる.ここで, 蚊の翅の $n$ 倍相似拡大モデルを考えると, $l_{c M}=n l_{c W}, l_{s M}=n l_{s W}$ であり，また式(4)に代入す ると $V_{M}=V_{W} / n$ である. 今, 翼モデルにおいて蚊の翅と同様のフェザリング運動を得るためには, 傾き角の振幅 が一致する必要がある，すなわち $\alpha_{W}=\alpha_{M}$ であり，式(6)，(7)及び式(8)，(9)に代入すると，

$$
E_{M} I_{M}=n^{2} E_{W} I_{W}
$$

となる. 従って, $n$ 倍拡大モデルには実際の蚊の $n^{2}$ 倍の曲げ岡性が必要であると言える. なお, 弾性力と慣性力 の比を表すコーシー数を用いても同様の結論に至る（石原他, 2010).

ここで式(10)に従えば, 10 倍拡大翼モデルは, 蚊の翅の 100 倍の曲げ岡性 $E_{M} I_{M}$ にななればならないはずであ る.しかし前章で示した結果では, 蚊の翅と同程度の場合にフェザリング運動を良好に再現しており，上記理論 と実駼結果に食い違いが生じている。

そこで比較検討のため, 上記理論に基づき, 曲げ岡性 $E_{M} I_{M}$ が蚊の翅の 100 倍の值を持つ 10 倍拡大翼モデル をシリコーンゴムにより作製した。 この翼モデルはPPS フィルムで作製したモデルと平面形状は同じであるが, 膜厚 $h_{M}=108 \mu \mathrm{m}, E_{M}=2.8 \mathrm{MPa}, I_{M}=1.87 \times 10^{-5} \mathrm{Nm}^{4}$ であり, 蚊の翅の翼弦方向の曲げ岡性の平均值 $53 \mathrm{pNm}^{2}$ の約 100 倍に相当する曲げ剛性 $E_{M} I_{M} \fallingdotseq 5.3 \mathrm{nNm}^{2}$ を持つ. このシリコーンゴム製翼モデルにおいて, 前章と同様に傾 き角 $\alpha$ の測定実験を行った結果を図 7 に示寸. 図 7 から, シリコーンゴム製翼モデルの傾き角 $\alpha$ の振幅は実際の蚊 のフェザリング運動と同程度であるが，時間的な変化は一致しておらず，別の振動波形が乗っている様子が確認 できる．これは，上記理論では実際の蚊の翅のフェザリング運動を再現するには不十分であることを示唆してい る. 実際の蚊の羽ばたき時のフェザリング運動と位相差が生じた主な原因としては, 実際の蚊の翅の質量は約 $11 \mu \mathrm{g}$ と非常に軽く慣性力が小さいのに対し, シリコーンゴム製の翼モデルでは比較的重く（約 $17 \mathrm{mg}$ ), 翼モデ ルの質量が無視できず, 慣性の影響が色濃く表れたためと推測される.シリコーンゴム製モデルに比べて軽い PPS

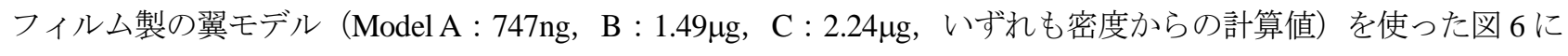


おいて，図７のような位相差が生じていないことからも慣性の寄与が示唆される。また質量が大きいことに加え て剛性が高いことにより，減衰力が相対的に低下寸る（減衰比が下がる）ため，振動が比較的減衰しにくいと考 えられる．それに伴い，実際の蚊の羽ばたきと振動波形に違いが生じたと考えられる．さらに，翼幅方向の変形 量の差がほとんど見受けられないが，これは周速度の違いによる変形量の差が上述の慣性や振動の影響に埋没し てしまった可能性が考えられる.

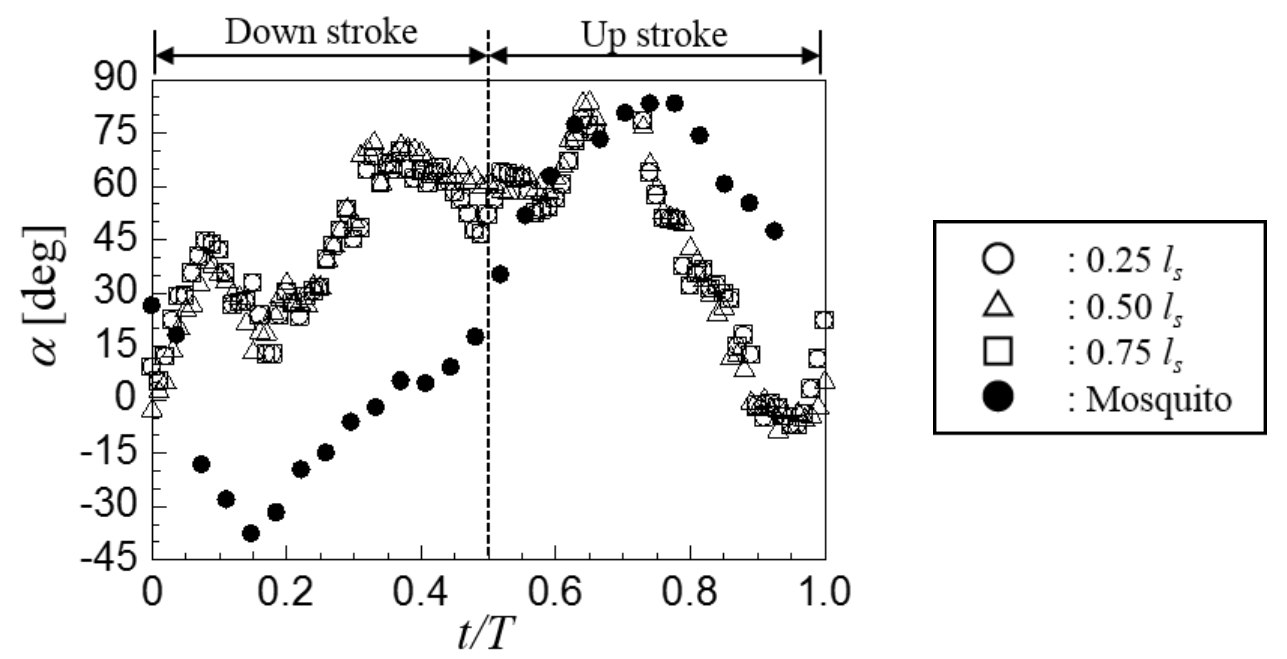

Fig. 7 The periodic changes of the inclination angle $\alpha$ of the 10 times enlarged wing model with silicone rubber. The bending stiffness of the model is 100 times as large as that of real mosquito. The amplitude of $\alpha$ is almost similar to that of mosquito's wing. The pattern of periodic change is mismatch.

このように，翼を片持ち梁と仮定した上記の簡易な理論やコーシー数だけでは，拡大モデルにおけるフェザリ ング運動を予測することが出来ない. これは，上記の理論やコーシー数では静的な議論しかしていないことが原 因として挙げられる. 従って, フェザリング運動の議論においては, 翼とその周囲の気流の動的な変動を考慮す る必要があると考えられる.一方で実験事実として 10 倍拡大モデルの翼弦方向の曲げ岡性は実際の蚊の翅と同程 度のときに実際の蚊と同様のフェザリング運動をすることが前章で示されており, 拡大前後で曲げ剛性を同じに する必要があることを裏付ける相似則の構築が必要である.

\section{6. まとめ}

蚊の羽ばたき飛行時に見られるフェザリング運動を模擬するため, 蚊の翅全体の翼弦方向の曲げ岡性を測定し た結果，平均約 $53 \mathrm{pNm}^{2}$ という值が得られた。 また，厚みの異なる PPS 樹脂を使って柔軟な 10 倍拡大翼モデルを 作製し，微風速風洞内で羽ばたき運動を観測した結果，蚊と同程度の剛性を持つモデルで良好なフェザリング運 動の再現に成功した．よって，実際の蚊も流体力により翅が受動的に変形することでフェザリング運動をしてい る可能性が裏付けられた. 加えて，10 倍拡大モデルにおいてフェザリング運動を再現するには，実際の蚊の翅と 同程度の曲げ剛性を与える必要があることが分かった。このことは既存の相似則では説明できないため，曲げ剛 性に関する新たな相似則の必要性が示唆された。

\section{文献}

東昭, 生物の動きの事典, 朝倉書店 (1997).

有田隆一, 加瀬篤志, 大場謙吉, 蚊の羽ばたき飛行のメカニズム解明のための実形状拡大翼フラッピングモデル

実験（運動量保存則による発生流体力の定量評価と翼迎え角が空力特性に与える影響），日本機械学会論文

集 B 編, Vol.77, No.775 (2011), pp. 422-430.

石原大輔, 山下祐, 堀江知義, 二保知也, ガガンボの飛行における受動的ピッチング運動と揚力発生に関する研

究，日本機械学会論文集 B 編, Vol.76, No.764 (2010), pp. 91-97.

加瀬篤志, 有田隆一, 大場謙吉, 蚊の羽ばたき飛翔メカニズムの解明, 油空圧技術, Vol.51, No.13(2012), pp.23-29. 
甲斐誠, 大場謙吉，蚊の羽ばたき飛行に関する実験的研究，日本機械学会論文集 B 編，Vol.67，No.654 (2001), pp. 147-154.

須藤誠一, 橋本弘之, 太田福雄, 片桐一成, 飛行昆虫の挙動解析 (トンボのはばたき特性), 日本機械学会論文集 B 編, Vol.60, No.579 (1994), pp. 10-16.

Sudhakar, Y. and Vengadesan, S., Flight force production by flapping insect wings in inclined stroke plane kinematics, Computers \& Fluids (2009), doi:10.1016/j.compfluid.2009.11.004.

\section{References}

Azuma, A., Encyclopedia of biotic motion, Asakura Publishing (1997).

Arita, R., Kase, A. and Ohba, K., Experiments of an enlarged realistic flapping wing model for elucidating mosquito's flight (A quantitative evaluation of generated aerodynamic forces by using a momentum conservation law and influence of attack angle for aerodynamic character), Transactions of the Japan society of mechanical engineering, Series B, Vol.77, No.775 (2011), pp. $422-430$ (in Japanese).

Ishihara, D., Yamashita, Y., Horie, T. and Niho, T., A study on the passive pitching and lift generation in crane-fly's flight, Transactions of the Japan society of mechanical engineering, Series B, Vol.76, No.764 (2010), pp. 91-97 (in Japanese).

Kase, A., Arita, R. and Ohba, K., Ka no habataki hisyou mechanism no kaimei, Yukuuatsu-gijyutsu, Vol.51, No.13 (2012), pp. 23-29 (in Japanese).

Kai, M. and Ohba, K., Experimental study of beating motion of mosquito, Transactions of the Japan society of mechanical engineering, Series B, Vol.67, No.654 (2001), pp. 147-154 (in Japanese).

Sudo, S., Hashimoto, H., Ohta, F. and Katagiri, K., Motion analyses of flying insects (Wing flapping characteristics of dragonfly), Transactions of the Japan society of mechanical engineering, Series B, Vol.60, No.579 (1994), pp. 10-16 (in Japanese).

Sudhakar, Y. and Vengadesan, S., Flight force production by flapping insect wings in inclined stroke plane kinematics, Computers \& Fluids (2009), doi:10.1016/j.compfluid.2009.11.004. 